\title{
The efficacy of fire and fuels reduction treatments in a Sierra Nevada pine plantation
}

\author{
Leda N. KobziarA,C, Joe R. McBride ${ }^{\mathrm{B}}$ and Scott L. Stephens ${ }^{\mathrm{B}}$ \\ A School of Forest Resources and Conservation, Institute of Food and Agricultural Sciences, \\ University of Florida, PO Box 110410, Gainesville, FL 32611-0410, USA. \\ ${ }^{B}$ Department of Environmental Science, Policy, and Managements, University of California, \\ Berkeley, 137 Mulford Hall, Berkeley, CA 94702-3114, USA. \\ ${ }^{\mathrm{C} C}$ Corresponding author. Email: Ikobziar@ufl.edu
}

\begin{abstract}
Plantations are the most common means of reforestation following stand-replacing wildfires. As wildfires continue to increase in size and severity as a result of fire suppression or climate change, establishment of plantations will likely also increase. Plantations' structural characteristics, including dense, uniform spacing and abundant ladder fuels, present significant wildfire hazards. Large-scale fuels reduction techniques may be necessary to reduce potential fire behavior in plantations and to protect surrounding forests. In the present study, four different manipulations aimed at reducing potential fire behavior in a Sierra Nevada pine plantation are compared. The treatments include: mechanical shredding, or mastication, of understorey vegetation and small trees; mastication followed by prescribed fire; fire alone; and controls. Fire behavior modeling shows that mastication is detrimental whereas prescribed fire is effective in reducing potential fire behavior at moderate to extreme weather conditions. Predicted fire behavior was compared with actual values from the prescribed burns in an effort to explore the limitations of fire modeling. Fire behavior predictions were similar to field observations in the more structurally homogeneous stands, but differed greatly where mastication created forest openings and patchy fuels distributions. In contrast to natural stands, the homogeneity of pine plantations make the results of the present work applicable to other regions such as the south-eastern US, where similar fuels reduction techniques are used to increase fire-resistance and stand resilience.
\end{abstract}

Additional keywords: fire behavior, fire modeling, mastication, Pinus jeffreyi, Pinus ponderosa, prescribed fire, thinning.

\section{Introduction}

In California alone, plantation forests cover nearly 162000 ha in the Modoc, Lassen, Plumas, Tahoe, El Dorado, Stanislaus, Inyo, Sierra and Sequoia National Forests combined (Landram 1996). The potential for extreme fire behavior exists in and around many of these plantations, and is linked to: high success rates in replanting and dense post-fire understorey growth; lack of fuels treatments; low summer fuel moistures; steep, mountainous terrain; frequent ignitions from lightning; and increased public recreation (ignitions) in national forests. These and other considerations have led to broad-ranging forest fuels reduction prescriptions for plantation and other forests on US public lands (HFRA 2003; Miller et al. 2009). The efficacy of the various available fuels reduction strategies for plantations has received little attention, but should be addressed before large-scale prescriptions are implemented. To be successful, fuels reduction prescriptions must be designed specifically for the forest type, the local environmental conditions, and the particular hazards associated with the surrounding vegetation and structures.

In fire-adapted ecosystems, evaluation of the longer-term goals of management prescriptions should reflect an understanding of the historical range of variability in that forest's fire regime (Morgan et al. 1994) and how changing climates may affect these forests (Millar et al. 2007). Although plantations are not naturally fire-adapted forest stands, they are considered the most effective means of reforestation after fire, and are often planted in areas with historically frequent fire return intervals. In addition, they are most often composed of fire-adapted species such as ponderosa pine (Pinus ponderosa Dougl. ex P. \& C. Laws) in the western US, and slash pine in the eastern US (Pinus elliottii Engelm.) and are subjected to the same ignitions and environmental conditions as their fire-prone predecessors and neighboring stands. Whether in natural or plantation forests, fire hazard reductions have the same ultimate goal: to manipulate forest structure so the possibility for large, stand-replacing fire is reduced. Such forest structures would then be considered fireresilient, or capable of sustaining natural fire occurrence with minimal loss of basal area (Agee and Skinner 2005; Vaillant et al. 2009).

Common principles of successful fuels reduction strategies for all forest types in the western US have been defined as: (1) reduction of surface fuels; (2) increases in the height to live crowns; (3) decreases in crown density; and (4) retaining of the largest trees in a stand (Agee and Skinner 2005). The techniques available for achieving these outcomes include mastication (shredding of understorey vegetation and small trees), various types of thinning (e.g. low thinning, or thinning from below; Keyes and O'Hara 2002), prescribed burning, and combinations 
thereof (Weatherspoon 1996; Omi and Kalabokidis 1998). Evaluations of the efficacy of such techniques in reducing potential crown fire behavior, and thereby increasing resilience after fire, must rely on fire behavior modeling, as experimental crown fires are not feasible in the dry forests of the western US. Evidence in other forests has been amassed by observing the effects of wildfires in fuels-treated areas (Weatherspoon and Skinner 1995; Schmidt et al. 2008; Safford et al. 2009), by modeling both fuels treatments and potential fire behavior (van Wagtendonk 1996; Stephens 1998), or by treating fuels and then modeling potential fire behavior (Kalabokidis and Omi 1998; Stephens and Moghaddas 2005a, 2005b; Stephens et al. 2009; Vaillant et al. 2009).

The present study couples fire behavior modeling with an analysis of predicted $v$. actual prescribed fire behavior to examine the effectiveness of four fuels reduction treatments in a Sierra Nevada pine plantation located in the Stanislaus National Forest of north-central CA. The manipulations include: (1) mastication of understorey and small trees; (2) mastication followed by understorey burning; (3) understorey burning alone; and (4) control. The overall objective is to evaluate the relative benefits of the treatments within the context of potential fire severity, and the eventual re-introduction of fire as a management tool in plantations.

\section{Methods \\ Background and site description}

In the Groveland Ranger District of the Stanislaus National Forest (SNF), $\sim 80 \%$ of the second-growth mixed-conifer vegetation has been significantly impacted by large ( $>1000$ ha) and typically high-severity wildfires since the 1970s. Ponderosa pine and Jeffrey pine (Pinus jeffreyi, Grev. \& Balf.) plantations were established following the stand-replacement Granite Fire of 1973 to restore forests to the burned area. Dense young stands (hereafter referred to as the 'Granite plantations') now cover 6000 ha of previously mixed-conifer forest habitat within the Ranger District and across the surrounding private timberlands, all located within $10 \mathrm{~km}$ west of Cherry Lake $\left(37^{\circ} 58^{\prime} 33^{\prime \prime} \mathrm{N}, 119^{\circ} 54^{\prime} 47^{\prime \prime} \mathrm{W}\right)$. The SNF Granite Stewardship Pilot Project includes a range of treatments designed to accomplish a wide array of goals in our study sites. Increased California spotted owl habitat, noxious weed elimination, stream restoration, road and meadow rehabilitation, vegetative diversity enhancement, improvement of tree health, and reduction of fire hazards were all included in the project scope. Specifically, the objectives of the silvicultural and burning prescriptions included wildfire hazard reduction (increased resistance), reduction of competition between trees, and creation of a more resilient plantation forest in the case of fire and other disturbances.

Extending from 1500 to $1800 \mathrm{~m}$ in elevation, the Granite plantations are influenced by a Mediterranean-type climate with summer drought and total annual precipitation averaging $130 \mathrm{~cm}, 80 \%$ of which is snowfall. Snowpack can at times linger through to the end of June. Summer drought conditions are common. Average summer and winter temperatures are 21 and $4^{\circ} \mathrm{C}$ respectively (WRCC 2005). Soils, formed from weathered granitic or metasedimentary rocks, are Inceptisols in the Pachic
Xerumbrepts class, and belong to the Fiddletown series. They are moderately deep to deep (50-100 $\mathrm{cm}$ depth), with a gravelly sandy loam texture in the upper horizons (USDA 1981). Slopes range from 13 to $22 \%$ with no significant differences between stands.

Seedlings planted on this substrate were germinated from seed sources within the local western-slope Sierra Nevada mixed-conifer forest type, and included Jeffrey pine, sugar pine (Pinus lambertiana Dougl.), ponderosa pine, Douglas-fir (Pseudotsuga menziesii (Mirb.) Franco), white fir (Abies concolor Gord. \& Glend), incense-cedar (Calocedrus decurrens [Torr.] Floren.), and infrequent giant sequoia (Sequoiadendron giganteum (Lindl.) Buchh). Ponderosa and Jeffrey pine comprise more than $90 \%$ of the pretreatment and over $95 \%$ of the post-mastication tree composition in all stands, with infrequent California black oak (Quercus kelloggii Newb.), and dogwood (Cornus nutallii Audubon ex. Torr. and Gray). The understorey is largely composed of shrubs such as whitethorn (Ceanothus cordulatus Kellogg), and greenleaf manzanita (Arctostaphylos patula E. Greene), with less abundant herbaceous species.

\section{Experimental design}

The Granite plantations were similar in aspect, slope, and soil type, and were between 5 and 82 ha in size. Permanent plots were established in replicated stands for three of the four treatments types, while the Burn Only treatment was only implemented in one stand. Due to a limited burn window (1 day) and other logistical constraints, the Burn Only treatment could not be replicated. Each plantation research stand consisted of seven 0.04-ha circular plots, arranged at $50 \times 50 \mathrm{~m}$ grid spacing with a randomized starting point location.

The fuels manipulation techniques included (1) mastication of small trees ( $\leq 23 \mathrm{~cm}$ in diameter) and surface fuels, all materials left on site (four Mastication replicates); (2) mastication of small trees as in (1), followed by understorey burning (two Mastication + Burn replicates); (3) understorey burning alone (one Burn Only replicate); and (4) control (five Control replicates) (Fig. 1). Stands used in the present study were randomly chosen from predetermined groups of stands assigned to particular treatment types, as defined by the USDA Forest Service. The mastication of trees $\leq 23 \mathrm{~cm}$ was used to decrease the density of stems to between $4 \times 4$ and $6 \times 6 \mathrm{~m}$ spacing, with emphasis on the removal of suppressed, diseased, or otherwise weakened trees. Four total stands underwent this treatment. Understorey shrubs and trees were also masticated, and all activity fuels (residual slash created by the mastication) were left on site. Mastication in units 2, 3, 4, and 5 was conducted between 2003 and 2004, and cost at an average of US\$1050 ha $\mathrm{hS}^{-1}$ (US\$425 acre ${ }^{-1}$ : K. Stillwell, pers. comm.). Burning in units 2 and 3 followed mastication, after fuels were left to cure for over a year. All burns were conducted on 28 June 2005, and the estimated cost was US\$1580 ha ${ }^{-1}$ ( $\sim$ US\$640 acre ${ }^{-1}$ : L. Johnstone, pers. comm.). Unit 1 had been masticated and pruned up to $2.5 \mathrm{~m}$ in the early 1990s, but was otherwise untreated before the burn. The remaining stands where pretreatment forest inventory, fuels, and vegetation data were collected served as controls. Controls were not treated for fuels reduction. 


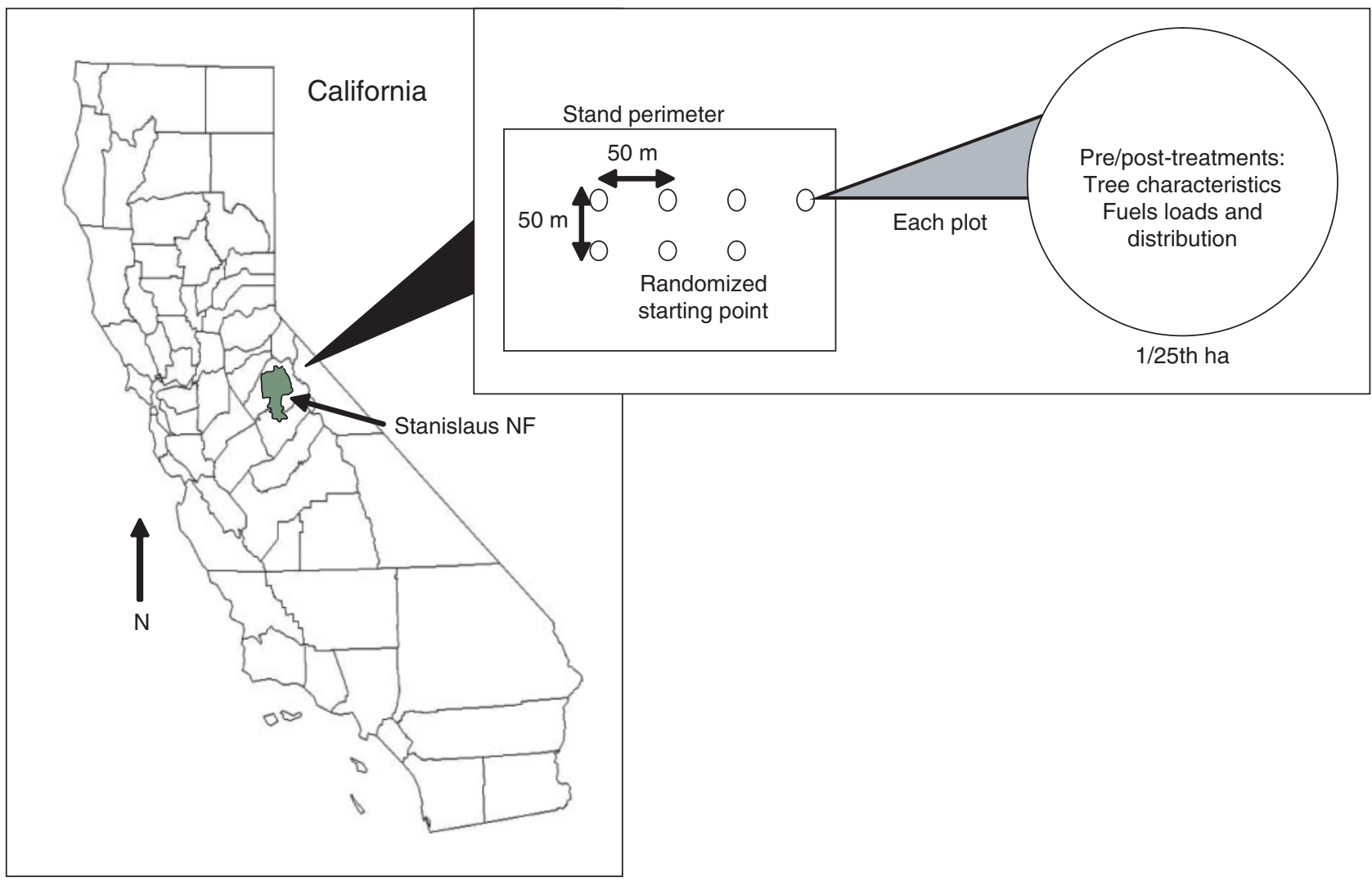

Fig. 1. Diagram of study design for each of the stands (five Control, four Mastication, two Mastication + Burn, one Burn Only). Seven $1 / 25$ th-ha plots were established on a $50 \times 50 \mathrm{~m}$ grid from a randomized starting point within the stand perimeters.

\section{Vegetation and fuels measurements}

In each of the 0.04-ha plots (63 total), all tree diameters, heights, live crown ratios, crown position (i.e. dominant, suppressed) and heights to live crown were documented, along with basal area, and percentage canopy cover before and after each treatment. Pretreatment data were collected from 2001 to 2002. Canopy cover was measured at five grid points per plot in each stand using a GRS densitometer or site tube (Geographic Resource Solutions $^{\mathrm{TM}}$, Arcata, CA) (Gill et al. 2000). There were no seedlings or saplings found within 0.004 -ha nested subplots centered at the center point of each of the seven plots per stand, and in each of the stands.

Both before and after manipulations, surface and ground fuel loads $\left(\mathrm{tha}^{-1}\right)$ were measured using the standard planar intercept technique (Brown 1974). In each plot, three fuels transects were established, resulting in a total of 189 transects for the overall study. Along the 10 -m-long transect, from 0 to $2 \mathrm{~m} 1$-h $(0$ $0.64 \mathrm{~cm})$ and $10-\mathrm{h}(0.64-2.54 \mathrm{~cm})$ fuels were sampled, whereas $100-\mathrm{h}(2.54-7.62 \mathrm{~cm})$ fuels were inventoried from 0 to $3 \mathrm{~m}$ and $1000-\mathrm{h}(>7.62 \mathrm{~cm})$ and larger fuels from 0 to $10 \mathrm{~m}$. Duff and litter depth in $\mathrm{cm}$ were measured at 5 and $10 \mathrm{~m}$ on each transect. Fuel depth $(\mathrm{cm})$ was measured at three points between 1 and $2 \mathrm{~m}$. Intercepted fuel particles were converted to fuel loads according to equations generated for California ponderosa pine forests (van Wagtendonk et al. 1996, 1998).

\section{Prescribed burning}

Three stands were burned on the same day in the late spring of 2005 . Although 28 June would typically be associated with summer and even fire-season conditions in this location, it was an uncharacteristically late spring throughout the Sierra Nevada, with precipitation falling through to the second half of June. In the study area, nearly $2 \mathrm{~cm}$ of rain fell on 17 June. Objectives for the prescribed burning treatments were to (1) reduce $1-100 \mathrm{~h}$ fuels to $1.1-6.7 \mathrm{tha}^{-1} ;$ (2) retain mature brush, down $\operatorname{logs}>38 \mathrm{~cm}$, and $5 \mathrm{~cm}$ of duff and litter; and (3) limit mortality to less than $20 \%$ of the preburn stand stocking.

In each of the three burned stands, $1 \mathrm{~h}$ before burning, fuel samples were collected to determine live and dead moisture contents on a dry weight basis. Each fuel type (1-h, 10-h, 100-h, 1000-h sound and rotten, live shrub, canopy, and duff and litter) had three replicates collected and oven-dried at $105^{\circ} \mathrm{C}$ for $24 \mathrm{~h}$. Fires were ignited using a combination of backing and strip-head fires (Martin and Dell 1978). Burning was conducted from 1000 to 2300 hours. Desired environmental conditions for the burns were achieved, including relative humidity measures between 25 and $60 \%$, windspeeds below $8 \mathrm{~km} \mathrm{~h}^{-1}$, temperatures between 0 and $24^{\circ} \mathrm{C}$, and 10 -h fuel moistures between 7 and $15 \%$ throughout the day. On-site weather data was measured hourly, and corroborated against a mobile Remote Access Weather Station (RAWS) that had been established within $0.5 \mathrm{~km}$ 
Table 1. Weather and fuel moisture conditions for modeled potential fire behavior and severity in ponderosa-Jeffrey pine plantations, Stanislaus National Forest, CA

\begin{tabular}{lcc}
\hline Variable & $\begin{array}{c}\text { 90th percentile } \\
\text { conditions }\end{array}$ & $\begin{array}{c}\text { 97.5th percentile } \\
\text { conditions }\end{array}$ \\
\hline Dry bulb temperature $\left({ }^{\circ} \mathrm{C}\right)$ & 31 & 33 \\
Relative humidity $(\%)$ & 19 & 13 \\
1-h fuel moisture $(\%)$ & 3.4 & 2.6 \\
10-h fuel moisture (\%) & 4.2 & 3.3 \\
100-h fuel moisture (\%) & 6.5 & 5.2 \\
Herbaceous fuel moisture (\%) & 54.2 & 45.4 \\
Woody fuel moisture (\%) & 70.5 & 65 \\
Probable maximum 1-min wind speed $\left(\mathrm{km} \mathrm{h}^{-1}\right)$ & 15 & 18 \\
Wind direction & $\mathrm{N}-\mathrm{NE}$ & $\mathrm{N}-\mathrm{NE}$ \\
\hline
\end{tabular}

of the burn stands. During the prescribed fires, rate of spread was timed using stop-watches between multiple segments of distance that had been marked on trees before the burn. Numerous fire effects monitoring personnel also estimated flame lengths. Flame lengths can be used to estimate fire line intensity (I) in $\mathrm{kW} \mathrm{m}^{-1}$ for each stand burned using the following equation from Byram (1959):

$$
\mathrm{I}=259.83 \mathrm{~L}^{2.17}
$$

where $\mathrm{L}=$ flame length $(\mathrm{m})$. This measure describes the rate of heat release per unit length of flaming front $\left(\mathrm{kW} \mathrm{m}^{-1}\right)$ and is associated with fire-caused injuries in aboveground plants (Van Wagner 1973). Post-fire sampling of fuel transects was conducted in the late summer and late fall of 2005.

\section{Potential fire behavior and effects modeling}

Fire Family Plus (Main et al. 1990) was used to determine fire weather conditions for modeling potential fire behavior at the 90th and 97.5th percentiles fire weather based on the Energy Release Component (Table 1). These percentiles represent fire weather associated with high and extreme fire behavior and often effects (e.g. intensity, severity) respectively. Climate information was compiled using a long-term RAWS dataset. The Mount Elizabeth RAWS station has collected data from 1961 to 1970, and from 1972 to 2003 , and is located $\sim 30 \mathrm{~km}$ from the sites at an elevation of $1504 \mathrm{~m}$.

Fuels Management Analyst (FMA) was used to model potential fire behavior and effects (Carlton 2004). Fire behavior output variables include average flame length, fireline intensity, size of fire $1 \mathrm{~h}$ after ignition, and torching and crowning indices (TI and CI). These indices portray the wind speed at $6.1-\mathrm{m}$ height that would result in torching (passive crown fire) or a sustained crown fire (active crown fire) (Scott and Reinhardt 2001). FMA utilizes published methodologies in its computations of potential fire behavior and crown bulk density, and crowning and torching indices for each stand evaluated. Stand characteristics are entered as an individual tree datum, including crown class (dominant, codominant, intermediate, or suppressed), live crown ratio, height, diameter, and species. Fire behavior modeling is based on the intersection of stand characteristics, fuel loads and distribution among timelag fuel classes, and fire weather. A detailed synopsis of methods used by FMA is outlined in Stephens and Moghaddas (2005a, 2005b).

\section{Data analysis}

Differences between pretreatment fuel loads and stand characteristics were evaluated using analysis of variance (ANOVA). Because all stands were not remeasured after each of the treatments, a standard repeated-measures analysis could not be employed. Instead, an analysis of covariance (ANCOVA) was used, with the prior measurement serving as the covariate for each stage of treatments and the post-treatment values as the response variables. Post-hoc comparisons of pairs (treatment types) of least-squares means were conducted using the Tukey Honestly Significant Difference test $(P<0.05)$ (Miliken and Johnson 2002; Stephens and Moghaddas 2005a). Because the Burn Only treatment was not replicated, it could not be included in the treatment effects analysis, but is discussed in terms of pre- $v$. post-fire differences. The Jump Statistical Software package was employed for all analyses (Sall et al. 2001). Modeled potential fire behavior and effects were not statistically compared, as the propagation of error associated with the numerous methodologies employed in their development would have precluded the detection of significant differences.

\section{Results}

\section{Stand and fuels characteristics}

Pretreatment stand and fuels characteristics did not differ between treatment types (Tables 2, 3). Following mastication, trees $\mathrm{ha}^{-1}$ were reduced while mean height to live crown, tree height, and diameter were significantly increased in the Mastication and Mastication + Burn stands relative to the Controls (Table 2). Mean basal areas were not significantly changed, although tree growth between the sampling years in Mastication + Burn stands (from 2001 to 2004) resulted in a slight increase in mean basal area even following mastication. This is probably a result of a lesser percentage of trees being removed in the Mastication + Burn stands $(32 \%)$ than in the Mastication stands (52\%). Canopy cover was reduced in the Mastication stands, but not in the Mastication + Burn treatment (Table 2). In these stands, increased canopy cover was, again, reflective of high growth rates between 2001 and 2004, and a lesser degree of tree removal.

When compared with the Controls, mean basal area was higher following mastication and burning (Table 2). The Burn Only mean diameter and height increased in relation to Controls 

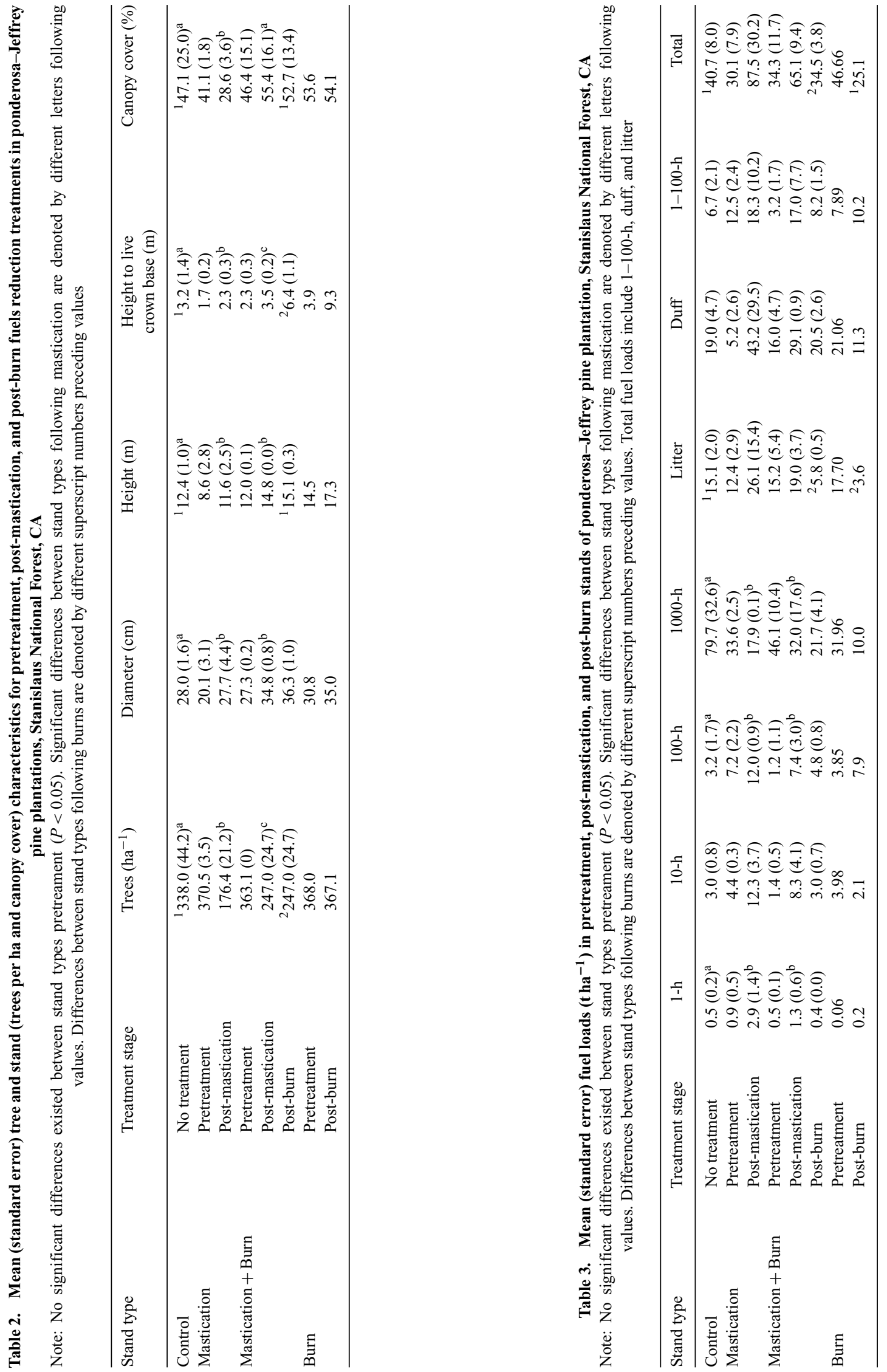
after burning, whereas height to live crown base increased in both Mastication + Burn and Burn Only manipulations (Table 2). Burning had no significant impact on canopy cover in burned stands, although scorched foliage had not fallen at the time of post-fire measurements.

The mastication prescription resulted in an increase in 1-h and 100-h fuels when compared with Controls (Table 3). Based on the analysis of covariance, there were no other detectable differences between fuel loads resulting from mastication. In the Burn Only stand, duff, litter, 1000-h, and total fuel loads were lowered, while 1-h and 100-h fuels increased relative to the preburn conditions. Following prescribed burning, all fuels were lower in Mastication + Burn stands in relation to their postmastication loads. When compared with pretreatment loads, 10-h and 100-h fuels along with duff load were still higher after fire in Mastication + Burn stands reflecting the effect of mastication on active fuels. Compared with the Controls, there were no detectable differences in total fuel loads following the prescribed burns (Table 3). In the Mastication + Burn and Burn Only stands, post-burning litter loads were lower than in the Mastication stands, whereas differences were not detectable when compared with the Controls. Burning reduced 1-h and 10-h fuel loads in the Mastication + Burn stands when compared with the Mastication treatment (Table 3).

\section{Fire modeling}

Potential fire behavior and effects were determined for the 80th, 90th, and 97.5th percentile fire weather and fuel moisture conditions, with the more severe (90th and 97.5th percentile) wildfire weather results shown in figures and Table 1. Fire rates of spread and flame lengths were similar between all stands before mastication. Mastication treatments resulted in longer flame lengths, faster rates of spread, and a greater potential for torching when compared with the Controls and pretreatment Burn Only stands (Figs 2, 3). Passive crown fire behavior was predicted for Control, Mastication, and Mastication + Burn stands: at the 97.5th percentile, mastication resulted in 100 and $50 \%$ passive crown fire behavior in the Mastication and Mastication + Burn stands respectively. Only surface fire behavior was predicted for the pretreatment and post-burn Burn Only stand, where pruning and mastication in the early 1990s had removed ladder fuels.

Following prescribed burning, rate of spread and flame length were markedly reduced in Mastication + Burn and Burn Only treatments when compared with Control and with Mastication treatments (Fig. 2), and fires were exclusively surface fires compared with at least $20 \%$ passive crown fire behavior in the Mastication stands. When compared with masticated and pretreatment Mastication + Burn and Burn Only stands, fire sizes $1 \mathrm{~h}$ after ignition were orders of magnitude lower after prescribed burning.

Canopy bulk density (CBD) in Mastication stands was reduced by mastication from 0.04 to $0.03 \mathrm{~kg} \mathrm{~m}^{-3}$, then restored to near pretreatment values following prescribed burning and stand growth. In the Mastication + Burn stands, CBD dropped from 0.06 to $0.05 \mathrm{~kg} \mathrm{~m}^{-3}$ following mastication, compared with $0.06 \mathrm{~kg} \mathrm{~m}^{-3}$ in Controls. In general, bulk density was lower following mastication and higher after burning $(\mathrm{CBD}=0.06$ $0.07 \mathrm{~kg} \mathrm{~m}^{-3}$ ) relative to Controls.
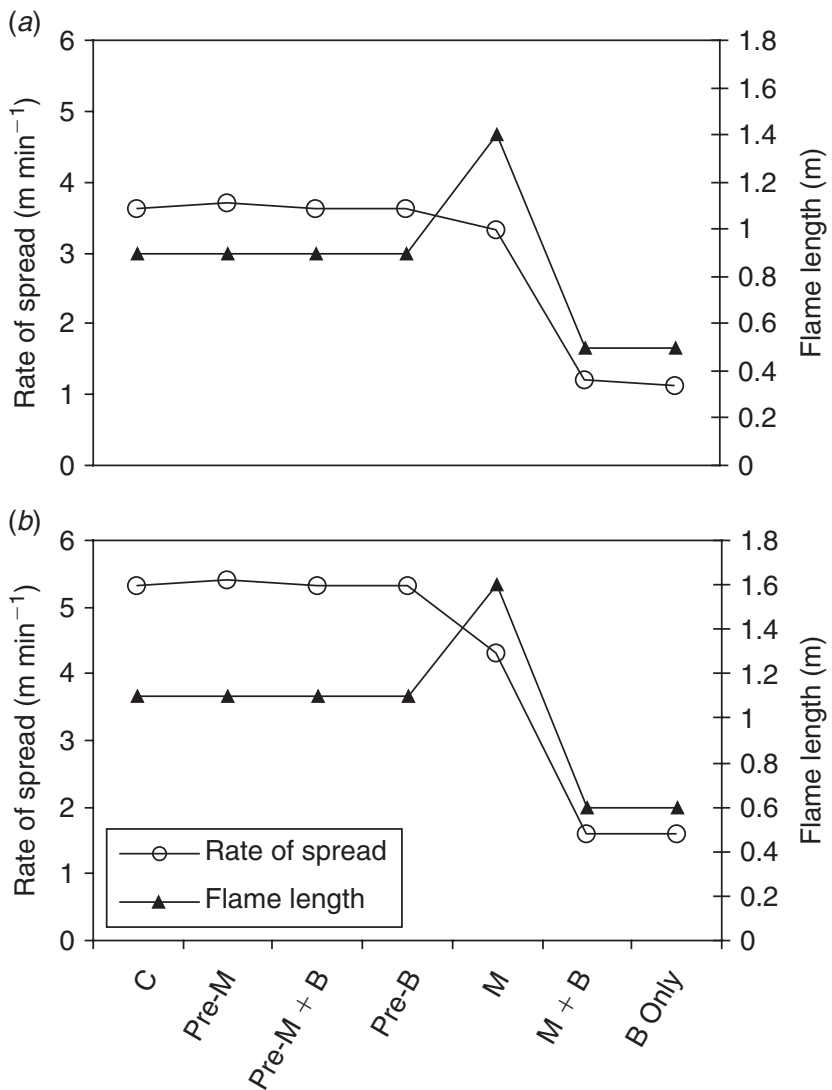

Fig. 2. Fire rate of spread and flame length under $(a)$ 90th and $(b) 97.5$ th percentile weather conditions in untreated $(C)$, and pre- and post-masticated (M), masticated then burned $(\mathrm{M}+\mathrm{B})$, and burned (B Only) pine plantations of the Stanislaus National Forest, CA.

\section{Predicted fire effects}

Because of the narrow range of diameters in the plantations, modeled mortality rates are shown within $10-\mathrm{cm}$ diameter ranges for each treatment stage in Fig. 4. Predicted mortality rates for trees of all diameters and weather scenarios were highest in masticated stands. Even under the 80th percentile weather scenario, over $95 \%$ of the smallest trees and over $35 \%$ of trees over $30 \mathrm{~cm}$ in diameter would succumb to fire in masticated stands. Only the fire treatments resulted in lower predicted mortality than in the Controls. In all pretreatment and post-burn stands, total mortality rates for larger-diameter trees $(\geq 31 \mathrm{~cm})$ were lower than $35 \%$ given either weather scenario (Fig. 4 ).

\section{Comparison of modeled and actual fire behavior}

Actual fuel moisture contents (dry weight) measured on the day of the prescribed burns, along with the environmental conditions described, were used as inputs for the FMA modeling of predicted fire behavior and percentage mortality in the three burned stands (Table 4). Stand characteristics entered for units 2 and 3 reflected post-mastication conditions $(\mathrm{M}+\mathrm{B} 1$ and $\mathrm{M}+\mathrm{B} 2)$ to mirror those in place during the actual burns. One-hour and duff fuel moistures were highest in $\mathrm{M}+\mathrm{B} 1$ and $\mathrm{M}+\mathrm{B} 2$ respectively. Ten- and 100-h fuel moisture contents were similar between the stands. 

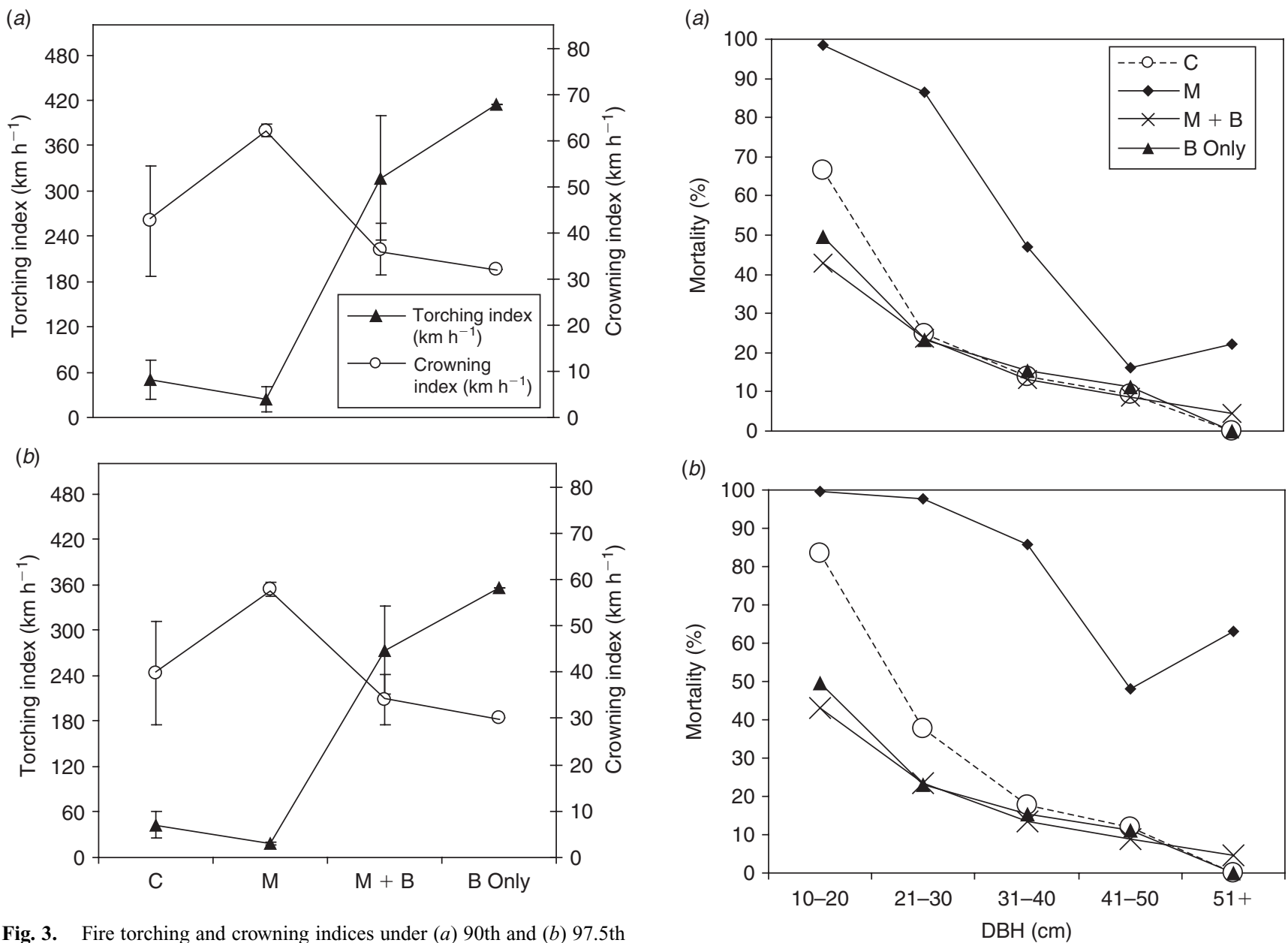

Fig. 3. Fire torching and crowning indices under $(a)$ 90th and $(b) 97.5$ th percentile weather conditions in Control (C), masticated (M), masticated then burned $(\mathrm{M}+\mathrm{B})$ and burned (B Only) pine plantations of the Stanislaus National Forest, CA.

Because the B Only stand burned only during the latemorning to afternoon hours, average relative humidity $(\mathrm{RH})$ was slightly lower, and because ignitions in the other two stands extended from the late afternoon until evening, average temperatures and RH were slightly higher (Table 4). Flame lengths, elliptical fire sizes and fireline intensities were generally higher in the actual fires than predicted by FMA (Table 4). In M + B1, modeled fire rate of spread and flame length were identical or nearly so to actual observed values (Table 4). The largest discrepancies between observed and predicted fire behavior metrics were in $\mathrm{M}+\mathrm{B} 2$ (Table 4).

\section{Discussion}

The need for fuels reduction treatments in the plantations is evidenced by predictions of crown fire behavior in the Control stands at 90th percentile weather conditions. When pretreatment fire behavior was evaluated, passive crown fire was predicted under extreme weather scenarios for $58 \%$ of experimental units. These stand-scale fuels manipulation experiments are an important first step in determining which techniques are most effective in increasing fire-resistance in pine plantations. We are aware of only one other empirical study that addresses fuels treatments

Fig. 4. Average predicted tree mortality across tree diameter (diameter at breast height (DBH)) categories under (a) 90th and (b) 97.5th percentile weather conditions in fuels-treated plantation stands, Stanislaus National Forest, CA (see Figs 2-3 for labels).

and potential fire behavior in western US plantations (Stephens and Moghaddas 2005b). Therefore, treatment effectiveness is also compared with results reported for other forest systems.

\section{Mastication of understorey and smallest trees}

Mastication resulted in increases in 1-100-h fuel loads, similarly to reports from other studies (Stephens and Moghaddas $2005 a$ ). The largest fuel loads (1000-h) decreased as a result of being mechanically reduced in size during the mastication procedure. A study using FMA to address fuels reduction treatments in Californian mixed-conifer stands found that mastication was effective in reducing potential torching and crown fire behavior, whereas fire rate of spread and flame lengths increased as a result of the addition of activity fuels (Stephens and Moghaddas 2005a). In Stephens and Moghaddas (2005a), the mitigation of crown fire behavior was attributed to increases in height to crown base, along with a reduction of ladder fuels. In contrast, in the Granite plantation, mastication resulted in a higher potential for torching in relation to the Controls, even with the 
Table 4. Modeled and observed fire behavior using actual burn condition variables in three prescribed burned stands in Stanislaus National Forest pine plantations, CA

\begin{tabular}{|c|c|c|c|}
\hline Actual burn conditions & B Only & $\mathrm{M}+\mathrm{B} 1$ & $\mathrm{M}+\mathrm{B} 2$ \\
\hline Dry bulb temperature $\left({ }^{\circ} \mathrm{C}\right)$ & 21 & 18 & 19 \\
\hline Relative humidity (\%) & 30 & 55 & 54 \\
\hline 1-h fuel moisture $(\%)$ & 2.3 & 10.0 & 5.3 \\
\hline 10-h fuel moisture $(\%)$ & 11.4 & 11.5 & 10.3 \\
\hline 100-h fuel moisture $(\%)$ & 12.3 & 10.5 & 11.7 \\
\hline Herbaceous fuel moisture (\%) & 75.9 & 69.4 & 74.8 \\
\hline Live woody fuel moisture (\%) & 53.6 & 51.7 & 50.1 \\
\hline Probable max. 1-min wind speed $\left(\mathrm{km} \mathrm{h}^{-1}\right)$ & 8.9 & 8.0 & 8.0 \\
\hline Wind direction & S-SE & E-SE & S-SW \\
\hline Fire type & Surface fire & Surface fire & Surface fire \\
\hline \multicolumn{4}{|l|}{ Fire behavior (modelled; observed) } \\
\hline Fire rate of spread $\left(\mathrm{m} \mathrm{min}^{-1}\right)$ & $1.1 ; 1.9$ & $0.8 ; 0.8$ & $0.9 ; 3.7$ \\
\hline Flame length (m) & $0.6 ; 0.8$ & $0.6 ; 0.7$ & $0.7 ; 1.1$ \\
\hline Fireline intensity $\left(\mathrm{kW} \mathrm{m}^{-1}\right)$ & $69.2 ; 151.5$ & $96.9 ; 116.1$ & $124.5 ; 313.3$ \\
\hline Torching index $\left(\mathrm{km} \mathrm{h}^{-1}\right)$ & 61.6 & 97.3 & 63.1 \\
\hline Crowning index $\left(\mathrm{km} \mathrm{h}^{-1}\right)$ & 33.5 & 45.1 & 44.5 \\
\hline Elliptical fire size (ha) & $0.3 / 0.3$ & $0.1 / 0.3$ & $0.2 / 0.4$ \\
\hline
\end{tabular}

decrease in crown bulk density. Because most trees in these plantations were of the same age and similar size, mastication did not effectively decrease ladder fuels; there were few ladder fuels to begin with. In addition, pretreatment shrub height in Mastication stands was less than $1 \mathrm{~m}$ on average, with mean percentage coverage less than $45 \%$. Although fire rate of spread was lower in masticated plantation stands than in the Controls, longer flame lengths contributed to a higher degree of predicted torching. Increased spacing between trees helped reduce the predicted active crown fire potential (crowning index). Yet the increase in spacing between trees and height to crown base was not effective in offsetting how the contribution of activity fuels influenced predicted fire behavior, and surface fire intensity has been linked to the initiation of crown fires (Van Wagner 1977).

These results are most similar to those reported by van Wagtendonk (1996) and Stephens (1998), where, when compared with numerous other fuels reduction manipulations, modeled fireline intensity and estimated mortality (based on scorch height) were highest in masticated and lop and scatter mixedconifer stands where activity fuels were distributed and left on site. Mastication treatments in younger $(<20$ years old) but structurally similar pine plantations also in the Sierra Nevada resulted in predictions of both passive and active crown fire behavior under weather conditions associated with intense fire behavior (Stephens and Moghaddas 2005a, 2005b), and potential rates of spread were nearly identical to those produced for the Granite stands. The difference in tree age and spacing, and associated canopy bulk density, between the two plantations likely explains why active crown fire was not predicted in the masticated Granite stands under even the most severe weather scenario. Mortality predictions were severe for the smallest size classes in both studies (Stephens and Moghaddas 2005b). In the Granite area, predicted mortality from fire under moderate weather conditions in masticated stands would result in a loss of nearly all trees under $30 \mathrm{~cm}$ in diameter, with overall losses averaging nearly half of all trees. In the present study, no treatment proved less effective at reducing potential wildfire severity and behavior. Over time, compaction of masticated materials could lower potential fire behavior, but the concurrent regrowth of understorey vegetation from residual root systems (i.e. Ceanothus and Arctostaphylos spp.) and seed banks should also be considered.

\section{Prescribed burning in masticated and untreated stands}

The increase of 1 -h fuels from 0.06 to $0.2 \mathrm{tha}^{-1}$ in the Burn Only stand may be attributable to fallen twigs from scorched canopies, but as both pre- and post-treatment measures indicate minimal, sparsely distributed 1-h fuel loads, this change is not likely to impact fire behavior. The forest floor in this stand is composed almost entirely of needle cast, and understorey vegetation is sparse. Another seemingly anomalous finding in the Burn Only stand, the increase in 100-h fuels after the burn, is attributable to the specifications of the sampling methodology. The Brown fuel transect sampling method instructs the researcher to tally fuels encountered along a transect line that are 'in and above the litter layer' (Brown 1974). The reduction in litter depth following the fire exposed more 100-h fuels, which, having been previously completely covered by the litter layer or embedded in the duff, probably evaded measure before the burn. Fuels of the 100-h timelag class were most likely accumulated in the early 1990s, when unit 1 was pruned and the sparse understorey was masticated. These fuels were also relatively wet before the burn, especially compared with the smaller fuel sizes, reducing their ignitability (Table 4). Such sampling error in stands characterized by a decade of surface fuels accumulations are likely in other Sierra Nevada forests, and should be accounted for via intermittent sampling for hidden coarse woody debris under the litter layer if feasible.

All post-mastication fuel loads in the Mastication + Burn treatment were reduced by the prescribed burn. In comparison with the pretreatment stands, the increase in 10-h and 100-h fuels due to mastication remained evident following the prescribed burn, and this is not surprising. These stands had heavy understorey shrub cover, and mastication transformed this vegetation 
from live to dead surface fuels. Decreases in fuel loads following the burn averaged $61.5 \%$ across all fuel classes. Although these decreases did not result in fuel loads significantly different from the Controls, they were lower than the Mastication stands. Prescribed burning has been shown to be one of the most effective fuels and fire severity reduction treatments in both modeled and empirical studies (van Wagtendonk 1996; Stephens 1998; Stephens and Moghaddas 2005a).

In ponderosa pine-dominated plantations, post-wildfire analysis found that plantations previously treated with understorey burning were less severely burned, and untreated plantations burned completely and severely (Weatherspoon and Skinner 1995). Also, from the edge of previously understorey-burned plantations inward toward the middle of the stands, wildfire behavior was markedly reduced in intensity and severity. In contrast to mastication alone, mastication plus prescribed fire or fire alone in our study sites were more effective in reducing potential fire behavior and severity. Compared with the Controls, the increases in height to live crown base in both burned treatment types along with the increase in tree diameter in the Burn Only treatment played a role in reducing potential mortality. Prescribed fire in both treatment types was the only manipulation that decreased modeled mortality for the smaller size classes ( $<30$-cm diameter), and overall in comparison with the Controls. Whether the mitigation of fire behavior provided by the three stands within the context of the larger (6000 ha) plantation is effective presents an interesting question for further research and fire modeling. The placement, timing, and size of fuels reduction treatments are each important in predicting their effectiveness on a landscape scale (Finney 2001).

\section{Actual and modeled fire behavior compared}

Because $\mathrm{M}+\mathrm{B} 1$ and $\mathrm{M}+\mathrm{B} 2$ had been masticated before the prescribed burning treatment, the fuel model incorporated into the FMA fire behavior and severity predictions was a slash-based model (Fire Behavior Prediction System, or FBPS fuel model 11; Rothermel 1972). This is in contrast to B Only, where fuel loads and distribution were best represented by a long-needle pine forest fuel model (FBPS fuel model 9). This may have explained the shorter predicted flame lengths and lower fireline intensity in B Only compared with the other two stands. Pruning treatments in B Only implemented in the early 1990s may have also impacted this finding. Among the three burned stands, the highest RH and lowest temperature corresponded to the lowest rates of fire spread and highest wind-speed index required for torching and crown fire behavior $(\mathrm{M}+\mathrm{B} 1) . \mathrm{M}+\mathrm{B} 1$ also had the lowest tree density, the fewest small trees $(<30 \mathrm{~cm}$ diameter at breast height (DBH)), and more large trees $(>40 \mathrm{~cm} \mathrm{DBH})$ in comparison with the other two stands. It is likely that these structural differences resulted in the high torching and crowning indices, along with lower predicted mortality rates.

In $\mathrm{M}+\mathrm{B} 1$, the predicted fire behavior was nearly identical to that observed, and in B Only, rate of spread and flame lengths were also similar. Discrepancies were greatest for $\mathrm{M}+\mathrm{B} 2$, where actual fire rate of spread was more than three times the rate predicted. The actual distribution of fuels in $\mathrm{M}+\mathrm{B} 2$ was quite patchy, with small forest openings dominated by live herbaceous species interspersed within areas of continuous and deep activity fuels. Ignitions in some areas of this stand therefore required more aggressive tactics than in the other two stands, and the resulting high rate of fire spread reflects this. It is likely, if only backing fire was used in $\mathrm{M}+\mathrm{B} 2$, that the predicted and observed fire behavior would have been better aligned. Importantly, like other fire behavior prediction models, FMA models wildfire behavior with a single ignition, whereas prescribed fire ignitions are repeated and often vary in patterns (line, point, spacing between lines and points) as well as in terms of the amount of fuel subjected to the ignitions.

\section{Management implications and applicability to other plantation forests}

As large-scale, severe wildfires continue to occur across the western US, plantations are likely to become a substantial component of the western forested landscape. Given the political and social attention to global climate warming, the importance of reforesting burned areas is destined to increase over the next few decades. Generally, the silvicultural model for plantation establishment uses dense spacing, followed by competing vegetation control (via herbicide use, prescribed burning, or mechanical removal), a precommercial thinning near mid-rotation, and finally a commercial harvest at rotation age. However, in western US public forests, reduction of competing vegetation or understorey fuels is often limited owing to: concerns for the safety of surrounding or embedded properties (e.g. wildland-urban interface areas), limited access, perceived negative environmental consequences, or ineffective cost incentives (Donovan and Brown 2005). The resulting build-up of surface and ground fuel continuity and load, along with the perpetuation of fire-hazardous stand structures, puts most western US plantations in fire-prone regions at risk.

In contrast, both public and private plantation owners in the south-eastern (SE) US engage in broad-scale control of competing vegetation, mainly using herbicides. Given the high rates of flammable vegetation regrowth and lightning ignitions across the south-east, such control is essential not only to reduce fire hazard, but to increase plantation growth rates and shorten the rotation age. On public lands in the SE US, the practice of repeated, widespread prescribed burning is well integrated in agency forest management planning and action. For example, by the end of August 2007, the south-eastern region of the US Forest Service (Region 8 ) had already prescribed-burned over 825000 ha of its 5 million hectare area, in contrast to less than 230000 ha across the remaining 73 million hectares of US Forest Service lands (http://www.nifc.gov/fire_info/ytd_state.htm, accessed 21 August 2009). Profitability, and therefore practice, of management techniques designed to reduce fire hazard differs drastically between the two regions. Timber from precommercial thinning in the south-east is readily used for pulp fiber products, and fiber mills are generally more numerous. In contrast, precommercial thinning has not proved cost-effective in the mountainous regions of the US, with the price of biomass removal commonly exceeding profits from its sales, if sales even occur (see Hesseln 2000).

Establishment of plantation forests in the western US should therefore follow a silvicultural model that takes these limitations into account, and explores alternative initiation options such as wider spacing, use of multiple species or uneven-aged management techniques, increased herbicide use (where appropriate), 
and increased application of the more cost-effective fuels reduction option: prescribed burning. Although prescribed burning cost estimates in these sites was high (owing to the small acreage, multiple burn locations, and perceived risk), average estimates for prescribed burning costs across US National Forests (from US $\$ 56$ to US $\$ 550 \mathrm{ha}^{-1}$; Cleaves et al. 2000) were at worst half that of our mastication costs (US\$1050 ha ${ }^{-1}$ ). The widespread application of such treatments may eventually be financially feasible, for instance, if mechanisms for biomass-to-energy are established in the western region. Although the practicality, implementation success, and timing of fuels treatments in the SE and western US differ, the structural characteristics of pine plantations are relatively homogeneous, making future investigations into fuels reduction efficacy, if not widely applicable, at least comparable between plantation types and regions. The results of the present work primarily lend insight into plantation forests where precommercial thinning and control of competing vegetation were not feasible or profitable, but where potential fire hazard is sufficiently high to warrant costly fuels reduction treatments.

\section{Conclusions}

In both untreated and post-mastication plantation stands, prescribed fire was the most effective fuels reduction technique, whereas mastication was least effective. Understorey burning was also most effective at decreasing potential fire behavior and severity, and in this sense, was successful in increasing both fire resistance and fire resilience in the plantation forest. However, there are important fire hazard tradeoffs between the treatment types that should be considered. In terms of reducing potential fire behavior, mastication (including small trees) has positive effects on stand structure, but negative impacts on fuel loads and continuity. In the context of ecosystem management and the influence of climate change, the relative ecological impacts and drivers of forest fuels treatments must also be considered (Kobziar et al. 2006; Kobziar 2007; Amacher et al. 2008; Moghaddas and Stephens 2008), while the spatial scale and patterning of treatments is critical to successfully reducing large fire potential (Omi and Kalabokidis 1998; Finney 2001; Agee and Skinner 2005). From a fire behavior perspective, it may prove more economical to establish western US plantations at wider spacing, as profits from precommercial thinning do not outweigh costs, and potential wildfire behavior would be less destructive for the duration of the rotation of the plantation stand. Understanding the limitations and evaluating the accuracy of fire behavior models can help managers target fuels reduction treatments to better achieve specific objectives. Such challenges can best be addressed through adaptive management approaches (Walters and Holling 1990; van Wagtendonk 1996) linked to continued experimentation and analysis of the efficacy of fuels reduction techniques in plantations.

\section{Acknowledgements}

This research was supported by funding from the USDA/USDI Joint Fire Science Program, which is responsible for this partnership between the Stanislaus National Forest and the University of California, Berkeley. For helpful reviews of the manuscript, thanks to Kevin O'Hara. Thanks to John
Swanson, Kathi Stillwell, Linda Johnstone, Allen Johnson, Dave McMenimen, Mike Lanier, and everyone at the Groveland Ranger District for supporting this research and bringing the burns to light. Thank you to HetchHetchy Water and Power for lodging. Domenico Caramango, Vincent Causse, Tim Vastine, Suzanne LaVoie, Lana Schide, and many others provided assistance during field sampling.

\section{References}

Agee JK, Skinner CN (2005) Basic principles of forest fuel reduction treatments. Forest Ecology and Management 211, 83-96. doi:10.1016/ J.FORECO.2005.01.034

Amacher AJ, Barrett RH, Moghaddas JJ, Stephens SL (2008) Preliminary effects of fire and mechanical fuel treatments on the abundance of small mammals in the mixed-conifer forest of the Sierra Nevada. Forest Ecology and Management 255, 3193-3202. doi:10.1016/J.FORECO. 2007.10.059

Brown JK (1974) Handbook for inventorying downed woody material. USDA Forest Service, Intermountain Forest and Range Experimental Station, General Technical Report GTR-INT-16. (Ogden, UT)

Byram GM (1959) Combustion of forest fuels. In 'Forest Fire: Control and Use'. (Ed. D Kenneth) (McGraw-Hill Book Company: New York)

Carlton D (2004) Fuels Management Analyst plus software, version 3.8.19. (Fire Program Solutions, LLC: Estacada, OR)

Cleaves DA, Martinez J, Haines TK (2000) Influences on prescribed burning activity and costs in the national forest system. USDA Forest Service, Southern Research Station, General Technical Report SRS-37. (Athens, GA)

Donovan GH, Brown TC (2005) An alternative incentive structure for wildfire management on National Forest land. Forest Science 51(5), 387-395.

Finney MA (2001) Design of regular landscape fuel treatment patterns for modifying fire growth and behavior. Forest Science 47(2), 219-228.

Gill SJ, Biging GS, Murphy E (2000) Modeling tree crown radius and estimating canopy cover. Forest Ecology and Management 126, 405-416. doi:10.1016/S0378-1127(99)00113-9

Hesseln $\mathrm{H}$ (2000) The economics of prescribed burning: a research review. Forest Science 46(3), 322-334.

HFRA (2003) Healthy forest restoration act. HR 1904. (United States Congress, Washington DC) Available at http://www.healthyforests.gov/ [Verified 7 March 2006]

Kalabokidis KD, Omi PN (1998) Reduction of fire hazard through thinning/ residue disposal in the urban interface. International Journal of Wildland Fire 8(1), 29-36. doi:10.1071/WF9980029

Keyes CR, O'Hara KL (2002) Quantifying stand targets for silvicultural prevention of crown fires. Western Journal of Applied Forestry 17(2), 101-109.

Kobziar LN (2007) The role of environmental factors and tree injuries in soil carbon respiration response to fuels treatments in pine plantations. Biogeochemistry 84, 191-206. doi:10.1007/S10533-007-9118-Y

Kobziar LN, Moghaddas J, Stephens SL (2006) Tree mortality patterns following prescribed fires in a mixed conifer forest. Canadian Journal of Forest Research 36, 3222-3238. doi:10.1139/X06-183

Landram M (1996) Status of reforestation on National Forest lands within the Sierra Nevada Ecosystem Project Study Area. In 'Sierra Nevada Ecosystem Project: Final Report to Congress, vol. III, Assessments and Scientific Basis for Management Options'. (Centers for Water and Wildland Resources, University of California: Davis, CA)

Main WA, Paananen DM, Burgan RE (1990) Fire Family Plus. USDA Forest Service, North Central Forest Experiment Station, General Technical Report GTR-NC-138. (Saint Paul, MN)

Martin RE, Dell JD (1978) Planning for prescribed burning in the inland northwest. USDA Forest Service, Pacific Northwest Forest and Range Experiment Station, General Technical Report GTR-PNW-66. (Portland, OR) 
Miliken GA, Johnson DE (2002) 'Analysis of Messy Data, vol. III: Analysis of Covariance.' (Chapman and Hall/CRC: London)

Millar CI, Stephenson NL, Stephens SL (2007) Climate change and forests of the future: managing in the face of uncertainty. Ecological Applications 17, 2145-2151.

Miller JD, Safford HD, Crimmins M, Thode AE (2009) Quantitative evidence for increasing forest fire severity in the Sierra Nevada and southern Cascade Mountains, California and Nevada, USA. Ecosystems 12(1), 16-32. doi:10.1007/S10021-008-9201-9

Moghaddas EEY, Stephens SL (2008) Mechanized fuel treatment effects on soil compaction in Sierra Nevada mixed-conifer stands. Forest Ecology and Management 255, 3098-3106. doi:10.1016/J.FORECO.2007.11.011

Morgan P, Aplet GH, Haufler JB, Humphries HC, Moore MM, Wilson WD (1994) Historical range of variability: a useful tool for evaluating ecosystem change. Journal of Sustainable Forestry 2, 87-111. doi:10.1300/J091V02N01_04

Omi PN, Kalabokidis KD (1998) Fuels modification to reduce large fire probability. In 'Third International Conference on Forest Fire Research, 14th Conference on Fire and Forest Meteorology', Vol. II, 16-20 November 1998, Luso, Portugal. pp. 2073-2088. (University of Coimbra: Coimbra, Portugal)

Rothermel RC (1972) A mathematical model for predicting fire spread in wildland fuels. USDA Forest Service, Intermountain Research Station General Technical Report INT-115. (Ogden, UT)

Safford HD, Schmidt DA, Carlson CH (2009) Effects of fuel treatments on fire severity in an area of wildland-urban interface, Angora Fire, Lake Tahoe Basin, California. Forest Ecology and Management 258, 773-787. doi:10.1016/J.FORECO.2009.05.024

Sall J, Lehman A, Creighton L (2001) 'JMP Start Statistics. A Guide to Statistics and Data Analysis Using JMP and JUMP IN Software.' 2nd edn. (Duxbury: Pacific Grove, CA)

Schmidt DA, Taylor AH, Skinner CN (2008) The influence of fuels treatment and landscape arrangement on simulated fire behavior, Southern Cascade range, California. Forest Ecology and Management 255, 3170-3184. doi:10.1016/J.FORECO.2008.01.023

Scott JH, Reinhardt ED (2001) Assessing crown fire potential by linking models of surface and crown fire behavior. USDA Forest Service, Rocky Mountain Research Station, Research Paper RMRS-RP-29. (Fort Collins, CO)

Stephens SL (1998) Evaluation of the effects of silvicultural and fuels treatments on potential fire behavior in Sierra Nevada mixed conifer forests. Forest Ecology and Management 105, 21-35. doi:10.1016/S03781127(97)00293-4

Stephens SL, Moghaddas JJ (2005a) Experimental fuel treatment impacts on forest structure, potential fire behavior, and predicted tree mortality in a California mixed-conifer forest. Forest Ecology and Management 215, 21-36. doi:10.1016/J.FORECO.2005.03.070
Stephens SL, Moghaddas JJ (2005b) Silvicultural and reserve impacts on potential fire behavior and forest conservation: twenty-five years of experience from Sierra Nevada mixed-conifer forests. Biological Conservation 125, 369-379. doi:10.1016/J.BIOCON.2005.04.007

Stephens SL, Moghaddas JJ, Ediminster C, Fiedler CE, Hasse S, Harrington M, Keeley JE, Knapp EE, McIver JD, Metlen K, Skinner CN, Youngblood A (2009) Fire treatment effects on vegetation structure, fuels, and potential fire severity in western U.S. forests. Ecological Applications 19, 305-320. doi:10.1890/07-1755.1

USDA (1981) Soil survey, Stanislaus National Forest Area, California USDA Forest Service, Pacific Southwest Region.

Vaillant NM, Fites-Kaufman JA, Stephens SL (2009) Effectiveness of prescribed fire as a fuel treatment in Californian coniferous forests. International Journal of Wildland Fire 18, 165-175. doi:10.1071/WF06065

Van Wagner CE (1973) Height of crown scorch in forest fires. Canadian Journal of Forest Research 3(3), 373-378. doi:10.1139/X73-055

Van Wagner CE (1977) Conditions for the start and spread of crown fire Canadian Journal of Forest Research 7, 23-34. doi:10.1139/X77-004

van Wagtendonk JW (1996) Use of a deterministic fire model to tes fuel treatments. In 'Sierra Nevada Ecosystem Project: Final report to Congress Volume II'. pp. 1155-1167. (Centers for Water and Wildland Resources, University of California: Davis, CA)

van Wagtendonk JW, Benedict JM, Sydoriak WM (1996) Physical properties of woody fuel particles of Sierra Nevada conifers. International Journal of Wildland Fire 6, 117-123. doi:10.1071/WF9960117

van Wagtendonk JW, Benedict JM, Sydoriak WM (1998) Fuel bed characteristics of Sierra Nevada conifers. Western Journal of Applied Forestry 13, 1145-1157.

Walters CJ, Holling CS (1990) Large-scale management experiments and learning by doing. Ecology 71, 2060-2068. doi:10.2307/1938620

Weatherspoon PC, Skinner CN (1995) An assessment of factors associated with damage to tree crowns from the 1987 wildfires in northern California. Forest Science 41(3), 430-451.

Weatherspoon PC (1996) Fire-silviculture relationships in Sierra forests. In 'Sierra Nevada Ecosystem Project: Final report to Congress Volume II'. pp. 1167-1176. (Centers for Water and Wildland Resources, University of California: Davis, CA)

WRCC (Western Regional Climate Center) (2003) Cherry Valley Dam, CA. Available at http://www.wrcc.dri.edu [Verified 21 December 2005]

Manuscript received 22 June 2006, accepted 9 September 2008 